\title{
Biological Effects of Stick Cherry, Soybean Seed and Licorice Root Extracts on Concentration of Serum Hormone Levels in Male Mice
}

\author{
Maysoon Mohammad Najeeb Mohammad Saleem, Ghassan Mohammad Sulaiman, \\ Arieg Abdul Wahab Mohammad and Abbas A. Mohammad \\ Biotechnology Division, Applied Science Department, University of Technology, Baghdad-Iraq.
}

\begin{abstract}
Background: This study was carried out to elucidate the effects of the oral administration of three types of herbs extract, stick cherry, soybean seed, and licorice root on concentration of the serum hormone, progesterone, testosterone, and estradiol in albino male mice.

Objective: we investigated the impact of biological activity of stick cherry, soybean seed, licorice root extracts on serum concentrations of reproductive hormone as compared with untreated group. Materials and Methods: A total of $\leqslant \wedge$ male mice were used in the experiment. The first group $\left(\mathrm{G}^{\prime}\right)$ was the control group which comprised Ir mice treated with $\cdot, 0 \mathrm{~mL} /$ day distilled water. The remaining ${ }^{\top \tau}$ mice were divided into $\left(G^{r}\right),\left(G^{r}\right)$, and $\left(G^{\varepsilon}\right)$. Each group comprised $1 r$ mice. The mice in these groups were orally treated for $Y$ lays with $\cdot, 0 \mathrm{~mL} /$ day stick cherry ethanol extract, soybean powder hexane extract, or licorice root ethanol extract at concentrations of $1 \cdot, 1 \cdot$, and $r \cdot \mathrm{mg} / \mathrm{kg} /$ day, respectively.

Results and Discussions: Results show the effect of stick cherry ethanol extract induced a significant increase in serum concentration of progesterone and testosterone, and a remarkable decrease in estradiol concentration. Soybean extract induced a significant increase in serum concentration of progesterone, testosterone, and estradiol in the treated group compared with the untreated group. No significant effect statistically was found in progesterone, estradiol, and testosterone levels occurred in the group treated with licorice root extract compared with the untreated group.

Conclusion: The extracts of stick cherry, and soybean seed exerts a remarkable effect on serum hormone concentration of reproductive organs, progesterone, testosterone and estradiol. Licorice root extract did not show any significant difference for all hormone levels. These extracts might be used as drugs and improve the function of reproductive organ or used as antifertility agents. There is no pharmacological or medical studies have evaluated the effect of stick cherry extract on reproductive hormones in male mice. Meanwhile, limited data and few references are available on the effects of soybean extracts licorice root on the serum hormone levels of reproductive organs.
\end{abstract}

Keywords: Progesterone, Estradiol Testosterone, Stick Cherry, soybeans, Licorice Root.

\section{Introduction}

Numerous chemical bioactive plant compounds are found in dietary sources such as fruits, vegetable, legumes, whole grains, seeds, herbs, and spices. Cherries (Prunus avium) are among the most delicious fruits, it is also popularly known as the "super fruit" because of its health benefits. Cherries are low in calories and high in antioxidants, which have significant health benefits and which provide good immunity against numerous diseases $[l, r]$. The antioxidant present in cherries destroys free radicals; hence, it protects body cells from damage and prevent the formation of atherosclerotic plaque and neurodegenerative diseases, and may improve memory $[r, \varepsilon, 0]$. Cherry anthocyanins exhibit a wide range of biochemical and pharmacological effects, and have been recommended as chemopreventive agents or nutritional supplements $\left[{ }^{\circ}\right]$.

Anthocyanins extracted from cherries exhibit anti-inflammatory properties by inhibiting cyclooxygenase activities [ $\left.{ }^{\top}\right]$. Cherries contain the oxidized form of vitamin $\mathrm{C}$, that is, dehydroascorbic acid, although the reduced form of ascorbic acid rarely occurs in fruits[ $\left.{ }^{\vee}\right]$. Aside from essential vitamins and minerals such as magnesium, potassium, dietary iron fiber, folate, and vitamin A (beta carotene), cherries contain phytochemicals that may lower the risks of cancer, heart diseases, and other chronic illnesses [\urcorner$, \vee, \wedge]$. Bioflavonoids, 
such as catechins, chlorogenic acid, flavonal glycosides, ellagic acid and other compounds, are also found in cherries. Tart cherries are also sources of other phenolic compounds, such as gallic acid, p-coumaric acid, kaempferol, and quercetin, which are all potent antioxidants $[9,1 \cdot, 1)]$. Anthocyanins increase the medical benefits of cherries; these compounds reduce several risk factors for heart disease and metabolic syndrome by lowering total cholesterol levels, reducing triglyceride levels $[1 \mathrm{Y}, 1 \mathrm{~T}$ ]

Soybean (Glycine max) is a species of legume from East Asia, it is widely grown for its edible bean which is extremely useful. Soybean seed contains high protein levels and a range of soluble carbohydrates that protect the cell viability of seeds [1 $\leqslant$ ]. Soybean also contains isoflavones such as genistein and daidzein. These compounds are among the sources of phytoestrogen in human diet. Isoflavones are considered useful by several dietitians and physicians in preventing cancer and other carcinogenic and endocrinedisruptive illnesse $[10,17]$. Soybean contains alpha-linolenic acid and a high level of phytic acid, which has numerous effects as an antioxidant and a chelating agent $[\mathrm{IV}]$. Isoflavones, such as genistein, act as oxidants that stimulate nitrate synthesis, block formation of new blood vessels, and inhibit substances that regulate cell division, cell survival, and growth factors $[11,19]$. However, the effects of plant hormones are limited, genistein is the predominant phytoestrogen in soybean which interacts with the estrogen receptors (ERs) alpha and beta, and elicits reproductive effects in developing rodents $[r \cdot]$.

Licorice (Glycyrrhiza glabra) is an herb that is both fragrant and flavorful, it has been used traditionally to treat respiratory problems, gastrointestinal ,cardiovascular, genitourinary, dermal and ocular diseases [ $\left.r^{\prime}\right]$. The pharmacological activities of licorice cover inflammation thirst, fever, chronic gastritis, hyperlipidemia and atherosclerosis atopic dermatitis, ulcer and others $[r,, r\}, r r]$.

The photochemical analysis of licorice root extract shows that the plant contains saponin, triterpenes (glycyrrhiza glycyrrhetinic acid and liquirtic acid), flavonoid, and other constituents such as coumarins, and polysaccharides; pectin, simple sugars, amino acid, tannins, choline, phytosterols, mineral salts, and various other substances $[r 1, r r, r \leqslant$, ]. The endocrine effects of licorice have been observed, and it has been demonstrated that inhibition of $11-\beta$-hydroxy steroid dehydrogenase by licorice block cortisol metabolism to cortisone, resulting in fetal growth retarding effects through material glucocorticoids. Also licorice affected metabolism by inhibiting $r \beta$-hydroxy steroid dehydrogenase and stimulating aromatase, resulting in reduced serum testosterone $\left[r_{0}, r^{\top}\right]$.

Progesterone has a key role in fertilization through its non-genomic signaling of human sperms as they migrate through the vaginal tract before fertilization occurs. However, the receptor responsible for such mechanism remains unidentified Progesterone has countless functions in both sexes and in all ages, such as blood sugar regulation, development of intelligence, bone building, brain activities, and more. Small amounts are produced by the adrenal glands, the brain, and the glial cells in both sexes $[Y \vee, Y \wedge]$. Progesterone has been investigated for its potential role in improving memory and cognitive ability. This hormone supports the normal development of neurons in the brain and exhibits protective effect toward damaged brain tissues $[r \wedge, r q]$. Testosterone is a steroid hormone from androgen group, and is one of the major sex hormones produced by the body in both men and women, It plays key roles in health and well-being. However, testosterone is also related to social psychology which includes aggression, power, sexual behavior, and social dominance. Social experiences, such as competition, can also increase or decrease testosterone level [r·]. Estradiol $\left(\mathrm{E}^{r}\right.$ or $(\vee \beta$-estradiol) is a sex hormone produced as an active metabolic product of testosterone. Estradiol is conjugated in the liver by sulfate and glucuronide formation, and excreted in the kidneys. This process is called enterohepatic circulation which contributes in maintaining estradiol levels. Estradiol has complex effects on the liver and may cause cholestasis. It also affects the production of multiple proteins, including lipoproteins, binding proteins, and proteins responsible for blood clotting $[r \cdot, r)]$. Estradiol is also produced in the brain and in the arterial walls, but it cannot be readily transferred from the circulatory system to the 
Journal of Al-Nahrain University

Science

brain .Testosterone is converted into estradiol in both sexes by aromatization $[r,, r r]$.

To our knowledge, studies on the effects of stick cherry on serum hormone levels is not properly documented. There is no pharmacological or medical studies have evaluated the effect of stick cherry on hormones of reproductive system in male mice. Hence, the present study investigate the effects of the oral administration of three types of extracts, namely, stick cherry, soybean, and licorice root on the concentration of serum hormones levels ,progesterone, testosterone, and estradiol in albino male mice.

\section{Materials and Methods \\ Extraction of stick cherry}

Stick cherries were collected from cherry fruits during summer and purified from a local herbal on a dish. The cherries were then airdried, ground into powder, and stored in a container until they are needed for extraction. Ground stick cherries $(0, \mathrm{~g})$ was added to $0 . \cdots \mathrm{mL} r . \%$ ethanol in a Soxhlet apparatus at $0 .{ }^{\circ} \mathrm{C}$ for $7 . \mathrm{min}$, and allowed to cool with slow mixing. Solution was then left in a rotatory evaporator at $7 .{ }^{\circ} \mathrm{C}$ until a thick solution was obtained. This solution was dried and stored in the refrigerator at $\varepsilon^{\circ} \mathrm{C}$. The dried extract was dissolved in distilled water to prepare the treatment with the concentration of 1. $\mathrm{mg} / \mathrm{kg} /$ day.

\section{Extraction of soybean}

Crushed soybean $(0 \cdot \mathrm{g})$ was weighed and mixed with $0 . . \mathrm{mL}$ hexane in a Soxhlet apparatus. The solution was then heated at $0 .{ }^{\circ} \mathrm{C}$ for ${ }^{\top} \cdot$ minutes before it was allowed to cool with continuous slow mixing. The solution was filtrated in rotator evaporator temperature for approximately ${ }^{\prime}$ day to $r$ days before it was stored in the refrigerator at $\varepsilon^{\circ} \mathrm{C}$. The dried extract was dissolved in distilled water to prepare the treatment with the concentration of $1 \cdot \mathrm{mg} / \mathrm{kg} /$ day.

\section{Extraction of licorice root}

Licorice root was extracted according to the following procedure. The root was purchased from the local herbal center in Baghdad. Iraq. The roots were air-dried before being pulverized and stored overnight at $\varepsilon^{\circ} \mathrm{C}$.
A total of $\mathrm{Y}^{\circ} \mathrm{g}$ crushed root were added to o.. mL $r . \%$ ethanol in a Soxhlet apparatus. The solution was heated at $0 .{ }^{\circ} \mathrm{C}$ for approximately $7 \cdot \mathrm{min}$, and then allowed to cool by mixing it slowly. The solution was left in a rotator evaporator set at $7 .{ }^{\circ} \mathrm{C}$ to obtain a thick solution. Finally, the product was allowed to dry and stored in the refrigerator at $\varepsilon^{\circ} \mathrm{C}$. The resulting deposit was dissolved in distilled water to prepare the treatment with the concentration of $r \cdot \mathrm{mg} / \mathrm{kg} /$ day.

\section{Laboratory animals and sample collection}

The albino male mice were provided by the Laboratory Animal Production Unit of the Biotechnology Division of the University of Technology. All mice were kept under constant environmental conditions at temperatures ranging from $r \Sigma^{\circ} \mathrm{C}$ to $r^{\circ}{ }^{\circ} \mathrm{C}$, with approximately $7 . \%$ humidity within a $1 Y$-hour light and dark cycle. The animals were supplied with water and food ad libitum. A total of $\varepsilon \wedge$ albino male mice weighing to $\mathrm{g}$ to $00 \mathrm{~g}$ with ages between $r$ months to $\Sigma$ months were used in this study. The mice were subjected to standard procedures, physically maintained, and used in accordance with the Guide for the Care and Use of Laboratory Animals of the Biotechnology Division, as approved by the University of Technology, Animal Ethical Committee. The mice were divided into four groups. The first group (labeled $\mathrm{G}^{\mathrm{l}}$ ), which comprised ir mice, served as the control group. The animals in this group did not receive herb extracts and were only given distilled water. The other groups (respectively labeled $G^{r}, G^{r}$, and $G^{\varepsilon}$ ) consisted of $1 r$ mice each. The animals in these groups received oral treatment for $r$ days. Treatments included $\cdot, 0 \mathrm{~mL} /$ day extracts of stick cherry in ethanol, soybean in hexane, and licorice root in ethanol at concentrations of $1 \cdot, 1 \cdot$, $r \cdot \mathrm{mg} / \mathrm{kg} /$ day, respectively. After $r$ days of treatment, all animals were sacrificed. Blood samples were collected by puncturing the heart. The samples were allowed to clot for 10 minutes at room temperature. Then, they were centrifuged and the serum was separated. The serum was used the same day for the analysis of hormones (progesterone, testosterone, and estradiol). 


\section{Biochemical assay of hormones}

Serum levels of Progesterone, estradiol, and testosterone were measured by ELIS KIT method via enzyme-linked immunosorbent assay (RIA) to determine their levels in the serum or plasma. The investigations were done in Al-Haarithea Laboratory in Bagdad.

\section{Statistical analysis}

Data were presented as mean \pm standard deviation (SD). To obtain data, individual values were tabulated using the statistical program GraphPad Prism version $0, .1$ (GraphPad Software, Inc., La Jolla, CA, USA). The difference between the means was assessed by Duncan's test, wherein $\mathrm{P} \leq \cdot, . \bullet$ is considered as significant.

\section{Result and Discussion}

Control of population growth is very important in populated countries. Numerous researches showed that the medicinal plant has an effect in changing of hormone levels of reproductive organs [ [rT]. Some species of plant have been studied for antifertility effect. It has been demonstrated that the Infertility effect of some plant such as Anethum graveolens was used in folk remedy to decrease male fertility are good sources to look for new agents. The treatment by this plant did not affect serum testosterone level from that of control group $[r r, r \varepsilon]$. Conventional drugs used as male contraceptive are often inadequate in population control. For this purpose several chemical substance and extract have been tested in animal models [ro]. The results of the present study illustrated in Tables ( $1, r$, and $r$ ). These tables show that there are a biochemical effect of these extracts solutions stick cherry, soybean seed, and licorice root on the reproductive hormones progesterone, testosterone, and estradiol. The extracts were administrated orally to the animals for three weeks at concentrations

of $1 \cdot, 1 \cdot$, and $r \cdot \mathrm{mg} / \mathrm{kg} /$ day, respectively. Table ( 1 ) illustrates a significant increase in the serum levels of progesterone $(\mathrm{P} \leq \cdot, \cdots)$, testosterone $(\mathrm{P} \leq \cdot, \cdot))$, in the treated animals with stick cherry at $1 \cdot \mathrm{mg} / \mathrm{Kg} /$ day as compared with the control group. The observed values in the treated animals are respectively $1 \cdot$ times and $V, r$. times higher than those in the untreated animals. Meanwhile, the serum level of estradiol is significantly reduced $(\mathrm{P} \leq \cdot, \cdot$,$) .$ The observed value in the treated animals is . $7 \wedge$ times lower than that in the untreated animals. This result can be attributed to the presence of antioxidants with neuroprotective functions. Estrogen is produced in the brain from steroid precursors. This hormone affects certain blood vessels and has been demonstrated to have a key role in improving arterial blood flow in coronary arteries $[\mid r, r \checkmark, r v$,$] . The elevation of progesterone$ level may be due to affected steroidogenesis function and ultrastructural changes in related cells of reproductive system and increase the number of mitochondria and dilate the smooth endoplasmic reticulum of cells $\left[r r, r^{\circ}\right]$.

Table ( $r$ ) shows the effect of soybean extract on the serum levels of progesterone, testosterone, and estradiol. It was observed a highly significant increase in the serum levels of progesterone $(\mathrm{P} \leq \bullet, \cdots)$ and testosterone $(\mathrm{P} \leq \cdot, \cdot)$. However, no significant elevation of estradiol level $(\mathrm{P}>\cdot, \cdot 0)$ was observed in the treated animals compared with the control group.

Photochemical is bioactive compounds that act as phytoestrogen. Soybean isoflavones may mimic the behavior of estrogen; however, this compound can also act as an anti-estrogen by reducing the effect of naturally produced estrogen. $[r \wedge, r q]$. The present study reveals that the short-term effect of the oral administration of soybean extract at a dose of ., $0 \mathrm{~mL} /$ day for three weeks results in an increase in the levels of serum progesterone and testosterone. This result may be related to soybean isoflavones and genistein, which produce a number of effects on reproductive tissues, immune functions, and neuroendocrine activities. The observed values in the serum levels of progesterone and testosterone are respectively $I V, \cdot r$ times and $1, \cdot$ times higher in the treated animals than in the animals in the control group.

The high fiber intake of soybean can also lower testosterone levels and is associated with a reduced risk of prostate cancer. In a study that aims to determine the effects of soybean 


\section{Journal of Al-Nahrain University Science}

on the reproductive health of healthy males, no significant effect of soybean on serum sex hormone testicular volume or semen quality was found $\left[\varepsilon_{\cdot}\right]$. These results indicate that the consumption of dietary phytoestrogens results in high plasma isoflavone levels over a relatively short period. This effect can significantly alter body and prostate weights, as well as plasma androgen levels without affecting gonadotropin or testicular levels $[r \cdot]$.

Glycyrrhizin has a chemical structure similar to that of the corticosteroids hormone released by the adrenal cortex. Studies have shown that glycyrrhizin stimulates the excretion of hormones by the adrenal cortex. The compound has been suggested as a possible drug for prolonging the action of cortisone. Further studies have also suggested that glycyrrhizin can be useful in improving the function of hormone drugs or can be used in reducing withdrawal symptoms from dependency on several corticosteroidal hormones. $[\leqslant 1, \varepsilon r]$.

Table ( $\Gamma$ ) revels that the effect of the oral administration of licorice root extract at $r \cdot \mathrm{mg} / \mathrm{kg} /$ day does not result statistically a significant differences in serum hormone levels of progesterone and testosterone and estradiol levels, $(\mathrm{P}>\cdot, \cdot 0)$ in the treated group as compared with the control group. The present results of effect of licorice root extract on testosterone hormone was in agreement with that illustrated in ref $[\varepsilon r]$, as it has been reported that serum testosterone level tended to decrease without statistically significant difference between the control (mean , , \& $\mathrm{r} \mathrm{ng} / \mathrm{ml}$ ) and treated (mean $\cdot, r \cdot$ , ${ }^{\top} \mathrm{r} \mathrm{ng} / \mathrm{ml}$ ) rats, following ${ }^{9}$ weeks treatment with licorice at high dose $(\uparrow \ldots \mathrm{mg} / \mathrm{Kg})$ group leading to reduction value of testosterone and did not show any abnormal signs. It was suggested that no observed adverse effect level of licorice extract at $0 \ldots, \ldots$ and at higher than $\mathrm{r} . . \mathrm{mg} / \mathrm{kg}$, the upper limit dose in the repeated dose toxicity protocol recommended in toxicity and that long term exposure to licorice might not cause profound adverse effects[ $\{r]$. It has been reported that licorice reduce the serum testosterone level and affected androgen metabolism by inhibiting the enzyme $\beta-r$ HSD, and IV $\beta$ HSD hydroxysteroid dehydrogenase or by stimulating aromatase. Therefore, it was proposed that licoric could cause the deficiency of serum testosterone, leading to sexual dysfunction or decline of libido in men $\left[r_{0,}, r_{T}, \varepsilon r\right]$.

Tamer et al. ( $\leqslant 1)$ has demonstrated that licorice affects the adrenal cortex by stimulating glucocortocoids production which effect the reproductive hormone. Small amounts of Testosterone are secreted by the adrenal glands and estradiol is also secreted to a lesser degree by the adrenal glands.

The effect of licorice on serum testosterone among healthy women was found to decrease because of the inhibition of $1 \mathrm{~V}$-hydroxysteroid dehydrogenase. This finding indicates that licorice may be beneficial in treating women with hirsutism and polycystic ovary syndrome

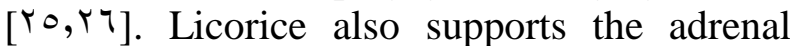
gland in stimulating excretion of hormones from the adrenal cortex and in promoting estrogenic activity.

\section{Conclusion}

There is no pharmacological or medical studies have evaluated the effect of stick cherry in male mice. Therefore, the present study reveals that the administration of Stick cherry ethanol extract has an effect on hormones of reproductive organs by enhancing the level of progesterone and testosterone but decline estradiol. This prevents oxidative stress as well as reducing damage to cells and affecting hormone production. Soybean extract enhances the levels of hormones of the reproductive organs and affects the endocrine system. Licoric root extract show no statistically significant difference between control and treated for progesterone and testosterone and estradiol in male mice. Different medicinal plant have an effect on changing the concentration of serum hormone level of reproductive organs So, plant used in folk remedy to decrease male fertitlity is good sources to look for new agents, or to improve reproductive system. This finding However, further studies are needed to investigate the effects of other hormones which are not included in the present work. 
Table (')

Effect of stick cherry extract on serum hormones level in mice.

\begin{tabular}{|c|c|c|}
\hline \multirow{2}{*}{ Hormones } & \multicolumn{2}{|c|}{ Mean $\pm S D$} \\
\hline & Untreated (control) & Treated \\
\hline Progesterone ng/ml & $r, I \vee r o \pm \cdot, \cdot V r T$ & $\mu 1,09 \pm 1, \wedge \Lambda \cdot *$ \\
\hline Testosterone ng/ml & $\cdot, \varepsilon \Lambda \mu \pm \cdot, r \leq V$ & $\Gamma, \varepsilon \vee 0 \pm \cdot, r \cdot r * *$ \\
\hline Estradiol pg/ml & 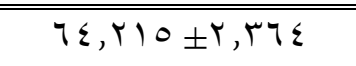 & $\varepsilon r, \wedge \vee \vee \pm r, ו r\urcorner * *$ \\
\hline
\end{tabular}

$*(P<\bullet, \ldots)$ very highly significant, $* *(P<\bullet, \cdot 1)$ highly significant.

Table ( $r)$

Effect of soybean powder extract on serum hormones level in mice.

\begin{tabular}{|c|c|c|}
\hline \multirow{2}{*}{ Hormones } & \multicolumn{2}{|c|}{ Mean $\pm S D$} \\
\hline & Untreated (control) & Treated \\
\hline Progesterone $\mathrm{ng} / \mathrm{ml}$ & $r, V Y \Delta_{ \pm} \cdot, \cdot V Y T$ & $0 \varepsilon, \cdot r r_{ \pm}, 077 *$ \\
\hline Testosterone $\mathrm{ng} / \mathrm{ml}$ & $\cdot, \varepsilon \Lambda \mu_{ \pm} \cdot, \cdot r \leq V$ & 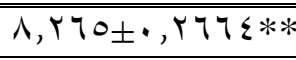 \\
\hline Estradiol pg/ml & $7 \varepsilon, Y \mid O \cdot \pm Y, Y\urcorner \varepsilon$ & $79, Y) \pm r, 0 \leqslant * * *$ \\
\hline
\end{tabular}

$*(P<\bullet, ., 1)$ very highly significant, $* *(P<\cdot, \cdot 1)$ highly significant, $* * *(P>\cdot, \bullet)$ not significant.

Table (")

Effect of Licorice root extract on serum hormones level in mice (as mean $\pm S D$ ).

\begin{tabular}{|c|c|c|}
\hline \multirow{2}{*}{ Hormones } & \multicolumn{2}{|c|}{ Mean $\pm S D$} \\
\hline & Untreated (control) & Treated \\
\hline Progesterone $\mathrm{ng} / \mathrm{ml}$ & $r, V Y \Delta_{ \pm} \cdot, \cdot V Y T$ & $\Gamma, r_{ \pm} \cdot, 10 \cdot * * *$ \\
\hline Testosterone $\mathrm{ng} / \mathrm{ml}$ & $\cdot, \Sigma \Lambda r_{ \pm} \cdot, \cdot r \leq V$ & $\cdot, 0, \gamma_{ \pm},,, \Gamma q * * *$ \\
\hline Estradiol pg/ml & $7 \varepsilon, Y 10 \cdot \pm T, Y \tau \varepsilon$ & $77,99 \pm 1,7 \vee * * *$ \\
\hline
\end{tabular}

$*(P<\cdot, \cdot 1)$ very highly significant, $* *(P<\cdot, \cdot 1)$ highly significant, $* * *(P>\cdot, \bullet)$ not significant.

\section{References}

['] Potapovich AI, Kostyuk VA. Comparative study of antioxidant properties and cytoprotective activity of flavonoids. Biochemistry, $r \wedge: 01 \leqslant \_019, r \ldots r$.

[r] Uzzan M, Labuza TP. Critical Issues in $R \& D$ of soy isoflavoneen enriched foods and dietary supplements. J. food Science, 79: ^V_ᄉ т, Y... .

[ץ] Rackova L, Oblozinsky M, Kostalova D, Kettmannand V, Bezakova L. Free radical scavenging activity and lipoxygenase inhibition of Mahonia aquifolium extract and isoquinoline alkaloids. J Inflammation, $\varepsilon:$ lo-r, r....

[ध] Kirakosyan A, Seymour EM, Noon KR, Urcuyo-Llanes DE, Kaufman PB, Warber
SF, Bolling SF. Interactions of antioxidants isolated from tart cherry (Prunus cerasus)

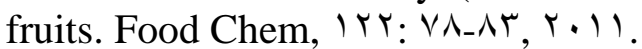

[०] Seymour EM, Ou B. Phytochemical and diverse antioxidant profile of whole tart cherries (Prunus cerasus) FASEB J, ro: $V V T, 1 \leq, r \cdot 11$.

[7] Seeram NP, Momin RA, Nair MG, Bourquin LD. Cyclooxygenase inhibitory and antioxidant cyanidin glycosides in cherries and berries. Phytomedicine, $\Lambda_{:} M_{4} r_{-}$ rчq, $r \cdots 1$.

$\left.{ }^{\vee}{ }^{\vee}\right]$ Johnston CS, Bowling DL. Stability of ascorbic acid in commercially available orange juices. J Am Diet Assoc, 1.r. oroor $9, Y \ldots r$. 
[^] Manach C, Scalbert A, Morand C, Remesy C, Jimenez L. Polyphennols: food sources and bioavailability. Am J Clin Nutr, $\vee q$ : $V Y V_{-} \varepsilon V, Y \cdots \varepsilon$.

[9] Kelley DS, Rasooly R, Jacob RA, Kader AA, Mackey BE. Consumption of Bing sweet cherries lowers circulating concentration of inflammation markers in healthy men and women. J Nutr, 147 : 911 . १人५, Y.. .

[1·] Kirakosyan A, Seymour EM, Llanes DEU, Kaufman PB, Bolling SF. Chemical profile and antioxidant capacities of tart cherry products. Food Chem, 110: Y.-Yo, $r$. . q

[' '] Tall JM, Seeram NP, Zhao C, Nair MG, Meyer RA, Raja SN. Tart cherry anthocyanins suppress inflammationinduced pain behavior in rat. Behav Brain

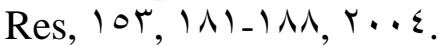

[1Y] Saleem MMNM, Mohammad AAW, Al-Amiery AAH, Hussan YK. In vivo study of cherry stick effect on concentration of serum total cholesterol, triglyceride and total protein in white albino male mice. $\mathrm{J}$ Fac Med Baghdad, or, $r \leqslant r-r \leqslant 0, r \cdot 1 \cdot$.

[1 $\left.{ }^{1}\right]$ Kim DO, Heo HJ, Kim YJ, Yang HS, Lee CY. Sweet and sour cherry phenolics and their protective effects on neuronal cells. J Agric Food Chem, or: 994 । _q9 $r v, r \ldots o$.

[1 [. Riaz MN. Soy applications in foods. London: CRC Taylor and Francis. pp. $\mathrm{q}_{-}$ Yr, Y... .

[10] Sacks FM, Lichtenstein A, Van Horn L, Harris W, Kris-Etherton P, Winston M, American Heart Association Nutrition Committee. Soy protein, isoflavones, and cardiovascular health: An American heart association science advisory for professionals from the nutrition committee. Circulation, $\left.11 r: 1 \cdot r \varepsilon_{-}\right) \cdot \varepsilon \varepsilon, r \ldots \tau$.

[17] Dillingham BL, McVeigh BL, Lampe JW, Duncan AM. Soy protein isolates of varying isoflavone content exert minor effects on serum reproductive hormones in healthy young men. J Nutr. Iro: 0^s_o91, r...0.

[IV] Sudheer Kumar M, Sridhar Reddy B, Kiran Babu S, Bhilegaonkar PM, Shirwaikar A, Unnikrishnan MK. Antiinflammatory and antiulcer activities of phytic acid in rats. Indian. J Exp Biol,

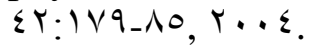

[1^] Gottstein N, Ewins BA, Ecclestn C, Hubbard GP, Kavanagh IC, Minihane AM, Weinberg PD, Rimbach G. Effect of genistein and daidzein on platelet aggregation and monocyte and endothelial

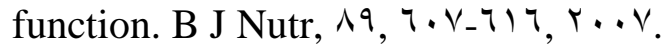

[19] Sasamura H, Takahashi A, Yuan J, Kitaura H, Masumori N, Miyao N, Itoh N, Tsukamoto T. Antiproliferative and antiangiogenic activities of genistein in human renal cell carcinoma. Urology, $7 \varepsilon$, rлq_rqт, r...

$\left[r^{\bullet}\right.$ ] Nagata $C$, Takatsuka N, Shimizu $H$, Hayashi H, Akamatsu T, Murase K. Effect of soymilk consumption on serum estrogen and androgen concentrations in Japanese men. Cancer Epidemiol Biomarkers Prev, 1., $\left|\vee q_{-}\right| \wedge \varepsilon, Y \cdots 1$.

[ץ'] Fiore C, Eisenhut M, Ragazzi E, Zanchin G, Armanini D. A history of the therapeutic use of liquorice in Europe. $J$ Ethnopharmacol, $99, \Gamma) V_{-} r \mathrm{r} \varepsilon, r_{\ldots} .0$.

[rr] Saleem M. M. N. M., Mohammad A. A., Al-Tameemi J. A., Sulaiman G. M. Biological Study of the effect of licorice roots extract on serum lipid profile, Liver enzymes and Kidney function tests in albino mice. African J. Biotechnol. 1•, IYV.r-IYV. T, Y. II.

$[r T$ Zhan C, Yang J. Protective effects of isoliquiritigenin in transient middle cerebral artery occlusion induced focal cerebral isachemia in rats. Pharmacol Res, or: r.r. $r \cdot q, r \ldots \tau$.

$[r \varepsilon]$ Ross IA. Glycyrrhiza glabra. Medicinal plants of the world. Chemical constituents, traditional and modern medicinal uses, Humana Press, Totowa, N. J. r: 191-r r.. l.

[Y०] Arminini, D., Fiore. C. Mattarello, M.J., Bielenberg, J., and Palemo, M History of endocrine effect of licorice. Exp. Clin. Endocrinol. Diabetes, $11 \cdot:$ YOV_r T , r..r.

[Yฯ] Arminini, D. Mattarello, M.J., Fiore, C., Bonanni, G., Scaroni C., Sartorato, P., and Palermo, M. Licorice reduce testosterone in healthy women. Steroid, 79, Vฯr_V r... . 
[YV] Thakur MK, Paramanik V. Role of steroid hormone coregulators in health and disease. Horm Res, $Y \backslash: 19 \varepsilon_{-} r \ldots, r \ldots q$.

[ ${ }^{\wedge}$ ] Pauli GF, Friesen JB, Godecke T, Farnsworth NR, Glodny B. Occurrence of progesterone and related animal steroids in two higher plants. J Nat Prod, $\vee r:$ r $\Lambda_{-} r \leqslant 0$, r.1.

[Yq] Schumacher M, Guennoun R, Robert F, Carelli C, Gago N, Ghoumari A, Gonzalez Deniselle MC, Gonzalez SL, Ibanez C, Labombarda F, Coirini H, Baulieu EE, De Nicola AF. Local synthesis and dual actions of progesterone in the nervous system: neuroprotection and myelination. Growth

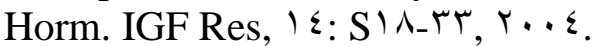

$\left[{ }^{\top \cdot} \cdot\right]$ Reed WL, Clark ME, Parker PG, Raouf SA, Arguedas N, Monk DS, Snajdr E, Nolan V, Ketterson ED. Physiological effects on demography: a long-term experimental study of testosterone's effects

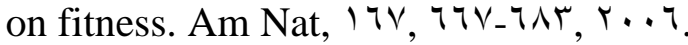

[r)] Carreau S, Lambard S, Delalande C, Denis-Galeraud I, Bilinska B, Bourguiba S. Aromatase expression and role of estrogens in male gonad: a review. Reprod Biol Endocrinol, 1 : ro, r... r.

$\left.{ }^{r}{ }^{r}\right]$ Pentikainen V, Erkkila K, Suomalainen L, Parvinen M, Dunkel L. Estradiol acts as a germ cell survival factor in the human testis in vitro. J Clin Endocrinol Metab, ${ }^{\circ} \mathrm{O}$ : r.OV_r. TV, r...

[rr] Malihezaman, M. and Sara P. Effect of Aqueous extract of Anethum graveolens (L.) on male reproductive system of rats. J. Biol. Sci. $\left.\vee: \wedge 10_{-} \wedge\right) \wedge, r \cdots \vee$.

[r飞] Monsefi, M., Ghasemi M. and Bahaoddini A. The effect of. Anethum graveolens L. on female reproductive system of rats. Daru, $1 \leqslant: 1)_{1}-1$ r $0, r_{\ldots} .7$.

[ro] Monsefi, M., Ghasemi M. and Bahaoddini A. The effect of of. Anethum graveolens L. on female reproductive

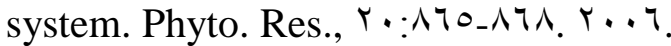

[YY] Lau F, Shukitt-Hale B, Joseph J. The beneficial effects of fruit polyphenols on brain aging. Neurobiol Aging, Yצ: I Y $\Lambda_{-} \mid T r$, r... 0 .

$[r \vee]$ Kirakosyan A, Seymour EM, Kaufman $\mathrm{PB}$, Bolling SF. The nature of the synergistic actions between medicinally active constituents in sour cherry (Prunus cerasus $L)$. Planta Med, $\vee ₹: S_{L} \wedge q, r \cdots \wedge$.

[rᄉ] Setchell KDR, Borriello SP, Hulme P, Axelson M. Non-steroidal estrogens of dietary origin: possible roles in hormonedependent disease. Am J Clin Nutr, $\varepsilon$ : $079 \_0 \vee \wedge, 19 \Lambda \varepsilon$.

[ץ9] Soucy NV, Parkinson HD, Sochaski MA, Borghoff SJ. Kinetics.,of genistein and its conjugated metabolites in pregnant sprague-dawley rats following single and repeated genistein administration. Toxicol Sci, $9 \cdot: r r \cdot-r \leq \cdot, r \cdot . T$.

[\&.] Weber KS, Setchell KD, Stocco DM, Lephart ED. Dietary soy-phytoestrogens decrease testosterone levels and prostate weight without altering $\mathrm{LH}$, prostate - alpha-reductase or testicular steroidogenic acute regulatory peptide levels in adult male Sprague-Dawley rats. J Endocrinol, IV: 091_099, r...'.

[§)] Tamir S, Eizenberg M, Somjen D etal. Estrogen like activity of glabredene and other constituents isolated from licorice

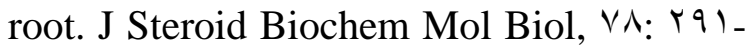
rq^, r... .

$[\varepsilon\}$ Maurya SK, Raj K, Srivastava AK. Antidyslipidaemic activity of glycyrrhiza glabra in high fructose diet induced dyslipidaemic Syrian golden hamsters. Indian $\mathrm{J}$ Clinc Biochem, $r \varepsilon_{:}: \varepsilon_{\cdot} \varepsilon_{-} \varepsilon_{\cdot} q$, r.. 9 .

$[\varepsilon r]$ Shin S, Jang JY, Choi BI, Baek IJ, Yon JM, Hwang BY, Park D, Jeon JH, Nam SY, Yun YW, Kim YB. Licoric extract does not impair the male reproductive function of rats. Exp. Anim. ov, $11-1 v, r \ldots \Lambda$.

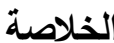

جريت هذه الدراسة لتبين تأثير التجريع الفموى لثلاثة

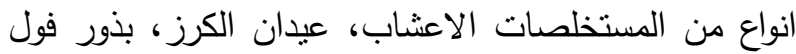

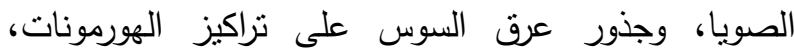

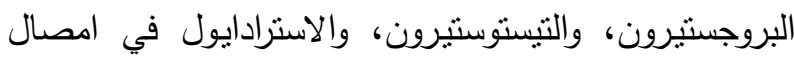
ذكور الفئران. تمت دراسة تأثنير الفعالية الحيوية لمستخلصات

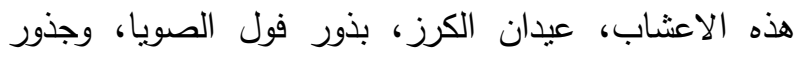

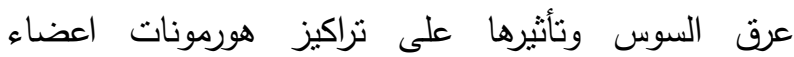




\section{Science}

التكاثرفى امصال ذكور الفئران بمقارنتها مع مجموعة

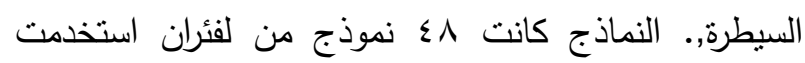

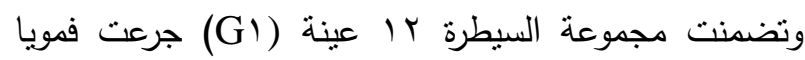

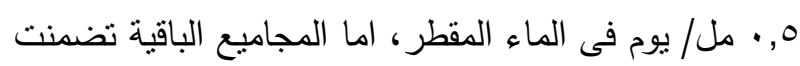

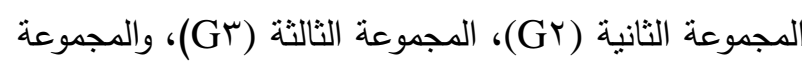
وشملت الرابعة كل مجموعة على ب ا حيوان ونم تجريع كل حيوان فمويا 0, • مل/ يوم من مستخلص الكحول الايثانولى لعيدان

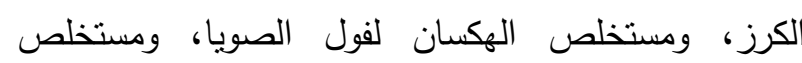
الكحول الايثانولى لجذور عرق السوس بتراكيز • ل1 و • و و و

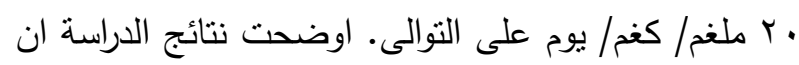

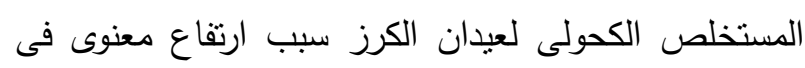

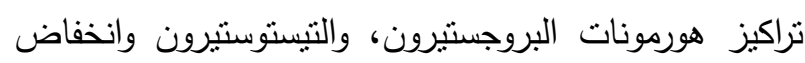
ملحوظ فى تراكيز الاسترادايول، ومستخلص فول ولئل الصويا

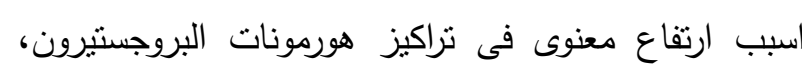
والتيستوستيرون، والاسترادايول بمقارنتها بمجموعة السيطرة. اما الفئران المعاملة بالمستخلص الكحولى الايثانولى لجذور عرق السوس لم يحدث اي اختلاف احصائى في مستويات تراكيزالهورمونات البروجستيستوسنتيرون والاسترادايول. بمقارنتها لمجموعة السيطرة نستتتج من دراستتا ان. مستخلصات عيدان الكرز، بذور فول الصويا، له ثأثثر

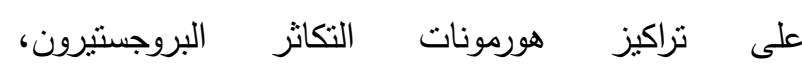

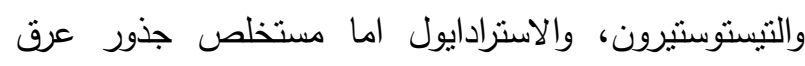
السوس ليس له اختلاف معنوى وتأثير ملحوظ لمسنويات هورمونات البروجسنيرون، والتيستوستيرون، والاسترادايول.

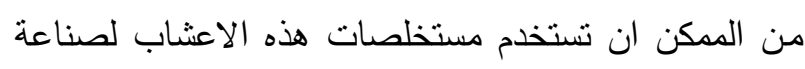

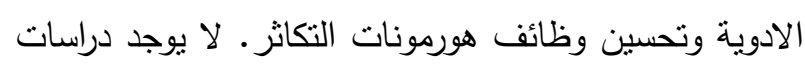

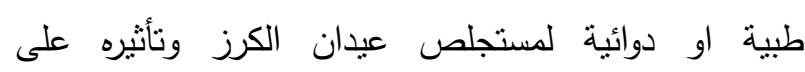
مستويات هورمونات التكاثر فى ذكور الفئران. 